\title{
Status ministra skarbu II Rzeczypospolitej Polskiej w obszarze spraw budżetowych
}

I. Podobnie jak współcześnie, w okresie międzywojennym szczególną rolę $\mathrm{w}$ administracji rządowej przypisuje się ministrowi odpowiedzialnemu za finanse państwa, zwłaszcza za budżet państwa. Analiza statusu prawnego ministra skarbu ${ }^{1}$, bo taką nazwą w okresie II RP, aż do 1950 r., określano ministra właściwego

\footnotetext{
${ }^{1}$ Nazwa „minister skarbu” wynika z historii skarbowości polskiej. Genezy urzędu ministra odpowiedzialnego za „skarb publiczny” i mennicę można doszukiwać się w urzędzie podskarbiego wielkiego koronnego. Szerzej: A. Filipczak-Kocur, Skarbowość Rzeczypospolitej 1587-1648, Warszawa 2006, s. 23-34, 224-238. W Konstytucji 3 maja minister skarbu został wymieniony expressis verbis jako członek Straży, czyli Rady Królewskiej (art. VII ustawy rządowej z dnia 3 maja 1791 roku, Volumina Legum, t. IX, 1889, s. 220-225). Konstytucja Księstwa Warszawskiego także wymieniała expressis verbis ministra przychodów i skarbu jako kierującego ministerium, a jednocześnie członka Rady Stanu - art. 11-15 Konstytucji Księstwa Warszawskiego z dnia 22 lipca 1807 r. (Dziennik Praw [Księstwa Warszawskiego] z 1807 r., t. I, s. II-XLVIII). Konstytucja Królestwa Polskiego z 1815 r. powołała zaś do życia Komisję Rządową Przychodów i Skarbu na czele z ministrem sekretarzem stanu - art. 76-77 ustawy konstytucyjnej Królestwa Polskiego z dnia 27 listopada1815 r. (Dziennik Praw Królestwa Polskiego z 1815, t. I, s. 1-103). W okresie rozbiorów ani w zaborze pruskim, ani austriackim - z uwagi na centralistyczny charakter rządów - nie powstał odrębny urząd ministra skarbu, a jeśli chodzi o zabór rosyjski, to włączenie polskiej administracji skarbowej w struktury rosyjskiego Ministerstwa Finansów nastąpiło dopiero po stłumieniu powstania styczniowego. Szerzej: B. Markowski, Administracja skarbowa w Polsce, Warszawa 1931, s. 52-68; R. Rybarski, Skarbowość polska w dobie rozbiorów, Kraków 1937, s. 9-26. Także w okresie pierwszej wojny światowej struktura administracji skarbowej była podporządkowana władzom państw okupacyjnych. W Cesarsko-Niemieckim Generalnym Gubernatorstwie Warszawskim, w Centrali Zarządu Cywilnego w Warszawie istniał wydział finansowy. Na terytorium okupowanym przez Austro-Węgry w ramach Urzędu Generalnego Gubernatorstwa Lubelskiego funkcjonował Oddział Skarbowy w Lublinie. Szerzej: W. Witkowski, Skarbowość na centralnych ziemiach Polski w czasie I wojny światowej [w:] C. Kosikowski (red.), System prawa finansowego. Teoria i nauka prawa fi-
} 
w sprawach budżetowych ${ }^{2}$, ma walor nie tylko czysto poznawczy, pozwala bowiem także zrozumieć i uzasadnić pozycję prawną współczesnego ministra finansów ${ }^{3}$. Ponadto na tle innych rozważań odnoszących się do odbudowy państwowości po okresie rozbiorów ważny wydaje się też element prawnofinansowy. Kompetencje ministra skarbu stanowią niejako soczewkę, w której skupiają się różne „wiązki” działalności państwa umożliwiające ową odbudowę i stworzenie jego nowoczesnych form. Dodatkowym argumentem przemawiającym za podjęciem badań w tym obszarze jest czynnik personalny, czyli wybitne osobowości piastujące stanowisko ministra skarbu (Władysław Grabski ${ }^{4}$, Eugeniusz Kwiatkowski ${ }^{5}$ i inni ${ }^{6}$ ), których dokonania zapisały się na kartach historii odradzającego się państwa. Refleksja nad statusem ministra skarbu to również okazja do spojrzenia na polskie regulacje skarbowe i ich znaczenie w układzie działalności władz państwowych.

Celem niniejszego artykułu jest ukazanie szczególnej pozycji prawnej ministra skarbu w obszarze spraw budżetowych oraz jego znaczącej roli w zakresie oddziaływania na gospodarkę finansową II RP, wyrażającej się w jego dyskrecjonalnych kompetencjach stawiających go nierzadko w uprzywilejowanej pozycji na tle innych ministrów czy organów. Przeanalizowane instytucje ówczesnego prawa skarbowego odnoszą się zarówno do procedury budżetowej, jak i różnych form gospodarki finansowej państwa: począwszy od funkcjonowania gospodarki pozabudżetowej i finansów komunalnych, na kwestiach zadłużenia kończąc. Chociaż współczesne regulacje prawnofinansowe są z natury rzeczy znacznie bardziej rozwinięte i skomplikowane pod względem materialno- i formalnoprawnym, to nie można ulegać wrażeniu, że są głęboko osadzone historycznie.

nansowego, t. I, Warszawa 2010, s. 151 i n. W gabinecie ministrów powołanym 26 listopada 1917 r. przez Radę Regencyjną utworzono Królewsko-Polskie Ministerstwo Skarbu. Zob. B. Markowski, Organizowanie administracji skarbowej w Polsce, „Ekonomista” 1927, t. IV, s. 14 i n.; por. W. Witkowski, Skarbowość na centralnych ziemiach..., s. 154. Na temat kształtowania się władz skarbowych w okresie II RP i etapów reform administracji zob. J. Przygodzki, Komisje dla usprawnienia administracji publicznej w II Rzeczypospolitej. Studium historycznoprawne, Wrocław 2019, passim; http://www.bibliotekacyfrowa.pl/Content/94326/Komisje_dla_usprawnienia_administracji_ publicznej_w_II_Rzeczypospolitej.pdf [dostęp: 15.11.2019].

${ }^{2}$ Ustawa z dnia 7 marca 1950 r. o przekształceniu urzędu Ministra Skarbu w urząd Ministra Finansów (Dz.U. 1950, Nr 10, poz. 101).

3 Szerzej: B. Kucia-Guściora, Status prawny Ministra Finansów w procedurze budżetowej oraz gospodarce finansowej jednostek sektora finansów publicznych, Lublin 2015, passim.

${ }^{4}$ Grabski Władysław Dominik (biogram), Narodowy Instytut Audiowizualny w Warszawie, http://www.biogramy.pl/a/biografia/wladyslaw-dominik-grabski-premier-wiesz [dostęp: 15.11.2019].

${ }^{5}$ Kwiatkowski Eugeniusz Felicjan (biogram), Narodowy Instytut Audiowizualny w Warszawie, http://www.biogramy.pl/a/biografia/eugeniusz-felicjan-kwiatkowski-1888-1974-polityk-chemikwiesz [dostęp: 15.11.2019].

${ }^{6}$ Z. Landau, Zapomniani Ministrowie Skarbu Drugiej Rzeczpospolitej, Warszawa 2005, passim. 
II. Zrekonstruowanie statusu prawnego ministra skarbu w obszarze spraw budżetowych w II Rzeczpospolitej jest możliwe dzięki analizie szeregu aktów prawnych. W okresie międzywojennym nie uchwalono bowiem jednego aktu prawnego, który obejmowałby swym zakresem prawo budżetowe i wynikające z niego prawa i obowiązki ministra skarbu?

Pierwszym aktem prawnym, w którym uregulowany został status ministra skarbu, był dekret Rady Regencyjnej z 1918 r. ${ }^{8}$ Minister skarbu stanął na czele dotychczas funkcjonującego Departamentu Skarbu z zadaniem przekształcenia go w Ministerstwo Skarbu9 . Do jego zadań określonych w sposób ogólny należały czynności związane z przygotowaniem, objęciem i zarządem wszelkich spraw wchodzących w zakres skarbowości państwowej oraz polityki finansowej państwa, podatków, ceł, spraw budżetowych, kredytowych, monetarnych i emisyjnych, a także nadzoru nad zakładami kredytowymi i asekuracyjnymi oraz wszelkiego rodzaju stowarzyszeniami kredytowymi ${ }^{10}$. Uwagę zwracają tu dwie kwestie. Po pierwsze, zakres spraw powierzonych ministrowi skarbu był dość szeroki. Po drugie, wśród spraw wchodzących w zakres skarbowości państwowej i polityki fiskalnej państwa wymienione zostały „sprawy budżetowe”. To na wniosek ministra skarbu budżet państwa był uchwalany przez Radę Ministrów, następnie przedstawiany Radzie Regencyjnej, a po jej powołaniu Radzie Stanu ${ }^{11}$. Wynika z tego, że tak ramowo sformułowane przepisy dawały ministrowi skarbu dość szerokie pole działania. W międzywojennej literaturze przedmiotu ministra skarbu określano jako ,redaktora preliminarza" 12 oraz ,redaktora ustawy skarbowej”, choć przede wszystkim zwracano uwagę na jego władztwo w zakresie kształtowania formalnej strony budżetu, która „bynajmniej nie jest bez znaczenia”"13. W doktrynie nie wahano się, oceniając status ministra skarbu, używać sformułowań: „autorytatywny sposób działania”, „supremacja”, a nawet „dyktatura finansowa”"14 zaś samego ministra nazywać „szafarzem skarbu polskiego" ${ }^{15}$. Warto dodać, że początkowo brak szczegółowych

${ }^{7}$ I. Weinfeld, Skarbowość polska, Warszawa 1935, s. 48; por. I. Czuma, Równowaga budżetu na tle prawa budżetowego różnych państw, Lublin 1924, s. 45 i n.; Z. Stahl, Istota budżetu na tle rozwoju historycznego i współczesnych tendencyj konstytucyjnych, „Archiwum Towarzystwa Naukowego we Lwowie" 1934, dział II, t. XIV, z. 4, s. 78.

${ }^{8}$ Dekret z dnia 3 stycznia 1918 r. Rady Regencyjnej o tymczasowej organizacji Władz Naczelnych w Królestwie Polskiem (Dz. Pr. K.P z 1918, Nr 1, poz. 1) [dalej: dekret Rady Regencyjnej].

${ }^{9}$ Art. 38 dekretu Rady Regencyjnej.

${ }^{10}$ Art. 25 dekretu Rady Regencyjnej.

${ }^{11}$ Art. 14 dekretu Rady Regencyjnej.

${ }^{12}$ C. Kosikowski, Pozycja prawna Ministra Skarbu w Polsce międzywojennej, „Finanse” 1973, nr 8, s. 61 .

13 A. Dubieński, Stanowisko Ministra Skarbu przy ustalaniu i wykonywaniu budżetu, Warszawa 1929, s. 7 i n.

${ }_{14}$ T. Grodyński, Metoda prawa budżetowego, Poznań 1938, s. 9.

15 I. Czuma, Równowaga budżetu..., s. 95. 
przepisów dotyczących kompetencji w zakresie kształtowania strony formalnej, a także materialnej ówczesnego budżetu sprawiał, że w praktyce to minister skarbu decydował o jego formie i wpływał na jego treśćc ${ }^{16}$. Jak słusznie się wskazuje, w praktyce konkretyzacja kompetencji ministra skarbu sprzyjała znacznemu ich rozszerzeniu z uwagi na konieczność stworzenia aparatu skarbowego, a przede wszystkim konieczność naprawy stanu finansów odrodzonego państwa polskiego ${ }^{17}$.

III. Znamienna była także tendencja do wzmacniania statusu ministra skarbu w kolejnych aktach prawnych. Należy jednak zauważyć, że w przepisach ustaw zasadniczych okresu międzywojennego pozycja ministra skarbu nie była odrębnie eksponowana. Jako na członku Rady Ministrów spoczywały na nim obowiązki i ponosił on odpowiedzialność na takich samych zasadach jak inni ministrowie ${ }^{18}$. Warto odnotować, że w kwestiach związanych z budżetem państwa, zaciąganiem długu publicznego, nakładaniem danin publicznych czy ustalaniem systemu monetarnego wymagana była forma ustawowa ${ }^{19}$. W zakresie spraw budżetowych (inicjatywa ustawodawcza, zamknięcia rachunków państwowych, absolutorium) podmiotem właściwym była Rady Ministrów ${ }^{20}$. Do oceny statusu ministra skarbu konieczna jest zatem analiza aktów prawnych i praktyki.

Pod względem organizacyjnym minister skarbu, podobnie jak inni ministrowie, zgodnie z aktami wykonawczymi Rady Ministrów ${ }^{21}$ był „naczelną władzą rządzącą w zakresie spraw mu powierzonych ustawami”. Był zwierzchnikiem wszystkich urzędników w ministerstwie, nadawał ogólny kierunek jego działalności i sprawował nad tą działalnością generalny nadzór. Ponosił także odpowiedzialność za kierunek polityki w swoim resorcie i działalność podległego mu ministerstwa. Przepisy wykonawcze $\mathrm{w}$ sposób szczegółowy określały zakres spraw wymagających bezpośredniej aprobaty ministra. Można tu wskazać jego uprawnienia w zakresie działalności legislacyjnej, kontaktów z innymi przedstawicielami władzy wykonawczej oraz przedstawicielami władzy ustawodawczej, spraw organizacyjnych i personalnych w ministerstwie.

${ }^{16}$ A. Dubieński, Stanowisko Ministra Skarbu..., s. 8.

17 Tak: C. Kosikowski, Pozycja prawna Ministra Skarbu..., s. 56.

18 Art. 55-63 ustawy z dnia 21 marca 1921 r. Konstytucja Rzeczypospolitej Polskiej (Dz.U. 1921, Nr 44, poz. 267 z późn. zm., dalej: Konstytucja marcowa); art. 25-30 ustawy konstytucyjnej z dnia 23 kwietnia 1935 r. (Dz.U. 1935, Nr 30, poz. 227, dalej: Konstytucja kwietniowa). Zob. także: A. Dubieński, Stanowisko Ministra Skarbu..., s. 14.

19 Art. 4, 6 Konstytucji marcowej; art. 50-51, 58-60 Konstytucji kwietniowej.

${ }^{20} \mathrm{Z}$ uwagi na charakter niniejszego opracowania szczegółowa analiza przepisów Konstytucji marcowej i kwietniowej pod kątem publicznej gospodarki finansowej nie jest możliwa.

${ }^{21}$ Rozporządzenie Rady Ministrów z 28 października 1920 r. w sprawie organizacji i zasad urzędowania Ministerstw (M.P. z 1920 r., Nr 251); rozporządzenie Rady Ministrów z 25 sierpnia 1926 r. w sprawie organizacji i urzędowania Ministerstw (M.P z 1926 r., Nr 203, poz. 578). 
Duże znaczenie dla wzmocnienia pozycji ministra skarbu miały dwa akty: uchwała Sejmu Ustawodawczego w przedmiocie uchwał sejmowych powodujących wydatki ze Skarbu Państwa ${ }^{22}$ oraz ustawa o środkach naprawy państwowej gospodarki skarbowej ${ }^{23}$. Pierwszy z wymienionych aktów stanowił swoiste zobowiązanie Sejmu do nieuchwalania wydatków bez zgody ministra skarbu do czasu uzyskania równowagi w budżecie Rzeczypospolitej. Było ono dalej idące, aniżeli zakładała Konstytucja marcowa, wymagająca, aby wnioski i projekty ustaw pociągające za sobą wydatki wskazywały sposób ich pokrycia ${ }^{24}$. Jak się podaje w literaturze, już przepisy ustawy zasadniczej pośrednio wzmacniały pozycję rządu i samego ministra skarbu, natomiast podjęta uchwała expressis verbis eksponowała jego stanowisko ${ }^{25}$. Zasadę zakazu uchwalania przez Sejm ustaw powodujących wydatki budżetowe nieznajdujące pokrycia w budżecie podniesiono do rangi normy konstytucyjnej w Konstytucji kwietniowej, z tym że jako organ udzielający zgody na odstępstwo od niej wskazano Radę Ministrów ${ }^{26}$. Drugi ze wskazanych aktów przyznawał ministrowi skarbu wyjątkowe uprawnienia władcze w kilku obszarach.

Po pierwsze, zgody ministra skarbu wymagały uchwały podejmowane przez Radę Ministrów, skutkujące wydatkami budżetowymi ${ }^{27}$. W tym wypadku chodziło nie tylko o projekty dotyczące spraw budżetowych (preliminarze czy prowizoria budżetowe), ale także o inne projekty ustaw, które pociągały za sobą wydatki. Literatura międzywojenna określała to uprawnienie ministra skarbu prawem veta ${ }^{28}$. Prawo veta czyniło z ministra „stróża równowagi budżetowej”229, było wyrażoną $\mathrm{w}$ formie ustawy zasadą, że polityka budżetowa musi być skupiona w rękach tego

${ }^{22}$ Uchwała Sejmu Ustawodawczego z dnia 16 grudnia $1921 \mathrm{r}$. w przedmiocie uchwał sejmowych, powodujących wydatki ze Skarbu Państwa (Dz.U. 1921, Nr 104, poz. 749).

${ }^{23}$ Ustawa z dnia 17 grudnia 1921 r. o środkach naprawy państwowej gospodarki skarbowej (Dz. U. 1921, Nr 103, poz. 741) [dalej: ustawa o środkach naprawy państwowej gospodarki skarbowej]. Została ona częściowo uchylona rozporządzeniem Prezydenta Rzeczypospolitej z 10 grudnia 1926 r. o utworzeniu Rady Finansowej przy Ministrze Skarbu (Dz.U. 1926, Nr 121, poz. 695), ale zmiana dotyczyła tylko Rady Finansowej, a nie innych kompetencji ministra skarbu. Uchylenie pozostałych kompetencji nastąpiło dopiero w 1949 r. ustawą z dnia 2 lipca 1949 r. o zakresie działania Ministra Skarbu (Dz. U. 1949, Nr 41, poz. 298).

${ }^{24}$ Art. 10 Konstytucji marcowej.

${ }^{25}$ I. Czuma wskazywał jednak na mankamenty przyjętej uchwały: prowizoryczny i sporny prawnie charakter. Zob. I. Czuma, Równowaga budżetu..., s. 101. Podobnie: G.L. Seidler, Ewolucja problemów budżetowych w polskim prawie państwowym, Kraków 1946, s. 12.

${ }^{26}$ Art. 50 ust. 3 Konstytucji kwietniowej.

${ }^{27}$ Art. 4 ustawy o środkach naprawy państwowej gospodarki skarbowej.

${ }^{28}$ Prawo veta ministra skarbu było postrzegane w literaturze jako zasadniczy punkt programu naprawy państwowej gospodarki skarbowej. Tak: Z. Landau, Zapomniani Ministrowie Skarbu..., s. 74 .

${ }^{29}$ B. Markowski, Administracja skarbowa..., s. 116. 
ministra, co daje gwarancję jej jednolitości i konsekwentnej realizacji ${ }^{30}$. Można także uznać, że instytucja veta zapewniała ministrowi skarbu dominację w rządzie.

Po drugie, minister skarbu posiadał kompetencje w zakresie funkcjonowania, kształtowania oraz porządkowania struktur organizacyjnych w państwie. Działając samoistnie lub w porozumieniu z premierem, miał prawo wglądu w sposób działania i tok urzędowania „władz, urzędów i zakładów państwowych oraz tych instytucji i zakładów niepaństwowych oraz zrzeszeń, które korzystają z pomocy materialnej Skarbu Państwa"31. Przepisy wyraźnie wskazują, że jest to prawo ministra, realizowane w razie potrzeby, w sposób jedynie informacyjny. Uzyskał on ustawowe upoważnienie do ,znoszenia istniejących państwowych władz, urzędów, zakładów, instytucji, placówek itp. organizacji wszelkiej nazwy cywilnych i wojskowych, których koszty utrzymania obciążają budżet państwowy, o ile ich istnienie i zakres działania nie opierają się na ustawie ani na rozporządzeniu Rady Ministrów"32. Ponadto zgoda ministra była wymagana do utworzenia nowych stanowisk służbowych w służbie cywilnej oraz przyjmowania funkcjonariuszy na wakujące stanowiska ${ }^{33}$.

Po trzecie, instrumentami przekazanymi ministrowi skarbu w celu naprawy państwowej gospodarki skarbowej były upoważnienia dotyczące kształtowania zasad zawierania umów zobowiązujących Skarb Państwa do świadczeń majątkowych, łącznie z sankcją nieważności umów nierespektujących tych zasad ${ }^{34}$ oraz zasadami wydzierżawiania majątku publicznego przedsiębiorstwom prywatnym ${ }^{35}$. Warto dodać, że realizacja polityki prooszczędnościowej była wzmacniana także przez inne instrumenty. Jednym z nich było powołanie przy Prezesie Rady Ministrów Nadzwyczajnego Komisarza Oszczędnościowego, którego decyzje miał prawo zatwierdzać minister skarbu ${ }^{36}$. Rozwiązania te były oceniane jako „kategoryczne zagwarantowanie praw ministra skarbu", nieznajdujące szerokiego zastosowania

${ }^{30}$ A. Dubieński stwierdzał wprost, że ,prawo veta zabezpiecza prawnie ministra skarbu przed niebezpieczeństwem przegłosowania na Radzie Ministrów, gdy chodzi o wydatki państwowe, jemu zapewnia w tych sprawach głos decydujący". Autor ten zdawał sobie sprawę z uwarunkowań pozaprawnych: politycznych, a także osobowościowych osoby piastującej urząd ministra, które miały istotne znaczenie w praktyce stosowania prawa veta. Pisał on, że minister „może się sprzeciwić powzięciu uchwały przez Radę Ministrów, ale nie może oczywiście zapobiec temu, by go nie wymieniono na ministra, który wyrazi zgodę na uchwałę". Zob. A. Dubieński, Stanowisko Ministra Skarbu..., s. 15. Podobnie: I. Czuma, Równowaga budżetu..., s. 96.

${ }^{31}$ Art. 1 ustawy o środkach naprawy państwowej gospodarki skarbowej.

${ }^{32}$ Art. 2 ustawy o środkach naprawy państwowej gospodarki skarbowej.

33 Art. 3 ustawy o środkach naprawy państwowej gospodarki skarbowej.

${ }^{34}$ Art. 4 ustawy o środkach naprawy państwowej gospodarki skarbowej.

${ }^{35}$ Art. 5 ustawy o środkach naprawy państwowej gospodarki skarbowej.

${ }^{36}$ Rozporządzenie Prezydenta Rzeczypospolitej Polskiej z dnia 28 stycznia 1924 r. o ustanowieniu Nadzwyczajnego Komisarza Oszczędnościowego (Dz.U. 1924, Nr 11, poz. 93). 
w ówczesnych państwach, pozwalające na zaliczenie Polski do grupy państw, których „teren egzekutywy był budżetowo scentralizowany”37.

IV. Na tle ogólnych przepisów wyznaczających pozycję ministra skarbu w okresie międzywojennym należy się odnieść do jego kompetencji w samej procedurze budżetowej. Przede wszystkim minister skarbu odgrywał szczególną rolę w procesie planowania budżetowego, co można stwierdzić na podstawie wielu aktów prawnych, a także ukształtowanej praktyki budżetowej.

Proces i zasady opracowywania materiałów niezbędnych do sporządzenia preliminarza budżetowego, rozumianego dzisiaj jako projekt budżetu ${ }^{38}$, nie zostały określone w prawodawstwie okresu międzywojennego. Na podstawie ogólnie przedstawionych kompetencji ministra skarbu w dekrecie Rady Regencyjnej, o którym była mowa wyżej, ukształtowała się praktyka budżetowa opracowywania przez ministra skarbu okólników o układaniu preliminarzy budżetowych, zwanych także notami budżetowymi. W okólnikach tych minister skarbu w sposób autorytatywny określał układ preliminarza budżetowego, terminarz prac, a także formalną stronę „wniosków władz naczelnych” co do wydatków ${ }^{39}$. Należy podkreślić, że z noty budżetowej wynikały założenia merytoryczne co do treści przyszłego preliminarza. Zalicza się do nich: normy dla ustalania wydatków rzeczowych oraz limity wydatków (,cyfrowe granice wydatków”), w tym limity dotyczące etatów, a także wydatków inwestycyjnych. Z uwagi jednak na brak określonej normatywnie formy prawnej okólnika trudno mówić o jego mocy wiążącej ${ }^{40}$, chociaż niektóre z okólników zawierały swoiste sankcje za nieprzestrzeganie zasad opracowywania preliminarzy przez poszczególnych ministrów ${ }^{41}$. Opracowanie preliminarza należało do Ministerstwa Skarbu. Na tym polu minister skarbu z uwagi na kompetencje związane z realizacją dochodów państwowych ${ }^{42}$, dążąc do zachowania równowagi budżetowej, musiał dokonywać ograniczenia wydatków. W związku

${ }^{37}$ I. Czuma, Równowaga budżetu..., s. 99.

${ }^{38}$ T. Grodyński, Zasady gospodarstwa budżetowego w Polsce na tle porównawczem, Kraków 1932, s. 10.

${ }^{39}$ A. Dubieński, Stanowisko Ministra Skarbu..., s. 8.

${ }^{40} \mathrm{~W}$ piśmiennictwie tego okresu wskazuje się, że dyrektywny charakter okólnika nie wynikał z ,prawa pisanego”, a uzależniony był od „pozycji i powagi Ministra”. Tak: I. Weinfeld, Skarbowość polska, s. 50.

${ }^{41}$ T. Grodyński przytacza przykład okólnika o układaniu preliminarza budżetowego na 1925 r., który zawierał sankcję odrzucenia przez ministra skarbu preliminarzy przygotowanych przez ministrów, w których nie zostały uwzględnione założenia przyjęte w okólniku, i przedłożenia Sejmowi preliminarzy opracowanych dla tych ministerstw przez Ministerstwo Skarbu. Zob. T. Grodyński, Zasady gospodarstwa budżetowego..., s. 247; por. C. Kosikowski, Pozycja prawna Ministra Skarbu..., s. 62 .

42 Według T. Grodyńskiego w okresie międzywojennym minister skarbu „dysponował” 80-90\% dochodów państwowych. Zob. T. Grodyński, Zasady gospodarstwa budżetowego..., s. 231. 
z tym płaszczyzną, na której przejawiała się jego szczególna pozycja w procesie przygotowania preliminarza budżetowego, były rokowania budżetowe czy konferencje budżetowe będące ,,polem do różnicy zdań, sporów i targów między Ministrem Skarbu a innymi ministrami"43. Należy wspomnieć, że pertraktacje te były rodzajem presji stosowanej przez ministra skarbu, której skutki miały co do zasady wymiar budżetowy (utrzymanie równowagi budżetowej), ale także polityczny ${ }^{44}$. Instrumentem wykorzystywanym w rokowaniach budżetowych, potwierdzającym uprzywilejowaną pozycję ministra skarbu, było omówione wyżej prawo veta wynikające z ustawy o środkach naprawy państwowej gospodarki skarbowej oraz wskazane w okólniku budżetowym (nocie budżetowej) górne limity wydatków dla poszczególnych części budżetowych.

Podsumowując, tok prac nad preliminarzem budżetowym potwierdza uprzywilejowaną pozycję ministra skarbu, kształtującego zarówno stronę formalną preliminarza, jak i ustalającego stronę dochodową oraz redagującego stronę wydatkową. Należy przyznać słuszność przedstawicielom przedwojennej doktryny, którzy zgodnie określali ministra skarbu mianem redaktora preliminarza ${ }^{45}$, który z uwagi na ukierunkowanie władczych kompetencji ${ }^{46}$ (wynikających nie tylko z ustawodawstwa, ale także z ówczesnych zwyczajów budżetowych ${ }^{47}$ ) nazywany był ministrem równowagi budżetowej ${ }^{48}$. Przyjęcie preliminarza budżetowego następowało w formie uchwały Rady Ministrów, która jako przedłożenie rządowe w konstytucyjnie określonym terminie wnoszona była do Sejmu ${ }^{49}$, z tym że preliminarze budżetowe w latach 1919-1924 nie były uchwalane w formie ustawy ani publikowane w Dziennikach Ustaw ${ }^{50}$. Moc wiążąca preliminarzy dla gospodarki

${ }^{43}$ A. Dubieński, Stanowisko Ministra Skarbu..., s. 10; por. I. Weinfeld, Skarbowość polska, s. 51.

${ }^{44}$ Minister Władysław Grabski wskazuje na różnicę zdań z ówczesnym ministrem spraw wojskowych gen. dyw. Kazimierzem Sosnkowskim podczas rokowań budżetowych, która spowodowała dymisję tego ostatniego. Zob. W. Grabski, Dwa lata pracy u podstaw państwowości naszej (19241925), Warszawa 1927, reprint: Lublin 2004, s. 34. Trzeba dodać, że w międzywojennej literaturze przywołana wyżej sankcja ,jednostronnego" ułożenia preliminarza przez ministra skarbu była „dość niezwykła" - tłumaczono ją faktem nie tyle silnej pozycji samego ministra skarbu, ile objęciem teki skarbu przez premiera Grabskiego. Zob. T. Grodyński, Zasady gospodarstwa budżetowego..., s. 247.

${ }^{45}$ A. Dubieński, Stanowisko Ministra Skarbu..., s. 7; T. Grodyński, Zasady gospodarstwa budżetowego..., s. 223.

${ }^{46}$ I. Czuma wskazywał, że minister skarbu nie był ,tylko mechanicznym kompilatorem budżetu z pojedynczych preliminarzy wydatków swoich kolegów”. Zob. I. Czuma, Równowaga budizetu..., s. 96.

47 T. Grodyński, Zasady gospodarstwa budżetowego..., s. 40-41.

${ }^{48}$ Ibidem, s. 232; I. Weinfeld, Skarbowość polska, s. 51.

${ }^{49}$ Art. 25 Konstytucji marcowej; art. 58 Konstytucji kwietniowej.

${ }^{50}$ Jak stwierdza T. Grodyński, były one podstawą gospodarki finansowej. Zob. T. Grodyński, Zasady gospodarstwa budzetowego..., s. 223. 
skarbowej wynikała z przyjętych uchwał Rady Ministrów. Zmieniło się to dopiero w 1924 r., kiedy po raz pierwszy została uchwalona ustawa skarbowa ${ }^{51}$. Procedura uchwalania ustawy skarbowej pozostawała domeną parlamentu ${ }^{52}$. Warto dodać, że w okresie międzywojennym zwyczajowo minister skarbu wygłaszał exposé budżetowe ${ }^{53}$.

Kompetencje ministra skarbu jako wykonawcy budżetu nie zostały uregulowane w sposób kompleksowy i uniwersalny w odrębnym akcie prawnym. Normy kompetencyjne wynikały z corocznych ustaw skarbowych ${ }^{54}$, ustaw zmieniających ustawy skarbowe ${ }^{55}$ oraz ustaw o prowizoriach budżetowych. $Z$ jednej strony charakterystyczna była zmienność podstaw prawnych działalności ministra skarbu, $z$ drugiej - w ustawach tych kategorie uprawnień ministra były zbliżone. Znamienne jest to, że wszystkie ustawy skarbowe w omawianym okresie zawierały ogólną normę kompetencyjną, która brzmiała: „wykonanie niniejszej ustawy powierza się

${ }^{51}$ Ustawa skarbowa obejmowała zarówno preliminarz(budżet), jak również inne postanowienia, które wiążą się z treścią budżetu. T. Grodyński, Zasady gospodarstwa budżetowego..., s. 11 i 99.

${ }^{52}$ Omówienie etapu parlamentarnego procedury budżetowej z uwagi na tematykę niniejszego artykułu zostanie pominięte. Szerzej: I. Weinfeld, Skarbowość polska, s. 55-59; T. Grodyński, Zasady gospodarstwa budzetowego..., s. 257-292.

${ }_{53}$ I. Weinfeld, Skarbowość polska, s. 55; T. Grodyński, Zasady gospodarstwa budżetowego..., s. 257.

${ }^{54}$ Ustawa skarbowa na rok 1924 z dnia 29 lipca 1924 r. (Dz. U. 1924, Nr 76, poz. 747); ustawa skarbowa z dnia 30 czerwca 1925 r. na rok 1925 (Dz.U. 1925, Nr 66, poz. 465); ustawa skarbowa z dnia 22 marca 1927 r. na okres od 1 kwietnia 1927 r. do 31 marca 1928 r. (Dz. U. 1927, Nr 30, poz. 254); ustawa skarbowa z dnia 22 czerwca 1928 r. na okres od 1 kwietnia 1928 r. do 31 marca 1929 r. (Dz.U. 1928, Nr 67, poz. 622); ustawa skarbowa z dnia 25 marca 1929 r. na okres od 1 kwietnia 1929 r. do 31 marca 1930 r. (Dz. U. 1929, Nr 20, poz. 183); ustawa skarbowa z dnia 29 marca 1930 r. na okres od 1 kwietnia 1930 r. do 31 marca 1931 r. (Dz.U. 1930, Nr 24, poz. 221); ustawa skarbowa z dnia 21 marca 1931 r. na okres od 1 kwietnia 1931 r. do 31 marca 1932 r. (Dz.U. 1931, Nr 28, poz. 188); ustawa skarbowa z dnia 18 marca 1932 r. na okres od 1 kwietnia 1932 r. do 31 marca 1933 r. (Dz.U. 1932, Nr 23, poz. 175); ustawa skarbowa z dnia 28 lutego 1933 r. na okres od 1 kwietnia 1933 r. do 31 marca 1934 r. (Dz. U. 1933, Nr 23, poz. 186); ustawa skarbowa z dnia 13 marca 1934 r. na okres od 1 kwietnia 1934 r. do 31 marca 1935 r. (Dz. U. 1934, Nr 27, poz. 219); ustawa skarbowa $z$ dnia 24 marca 1935 r. na okres od dnia 1 kwietnia 1935 r. do dnia 31 marca 1936 r. (Dz.U. 1935, Nr 21, poz. 121); ustawa skarbowa z dnia 30 marca 1936 r. na okres od 1 kwietnia 1936 r. do 31 marca 1937 r. (Dz. U. 1936, Nr 23, poz. 185); ustawa skarbowa z dnia 29 marca 1937 r. na okres od 1 kwietnia 1937 do 31 marca 1938 r. (Dz. U. 1937, Nr 23, poz. 147); ustawa skarbowa z dnia 29 marca 1938 r. na okres od 1 kwietnia 1938 r. do 31 marca 1939 r. (Dz. U. 1938, Nr 20, poz. 161); ustawa skarbowa z dnia 29 marca 1939 r. na okres od 1 kwietnia 1939 r. do 31 marca 1940 r. (Dz.U. 1939, Nr 27, poz. 177).

${ }^{55}$ Ustawa skarbowa z dnia 22 lipca 1925 r. o dodatkowych kredytach na rok 1925 (Dz.U. 1925, Nr 83, poz. 570); ustawa skarbowa z dnia 22 lipca 1925 r. o zmianach w budżecie na rok 1924 (Dz.U. 1925, Nr 90, poz. 634); ustawa skarbowa z dnia 13 lipca 1927 r. o zmianach w budżecie na rok 1925 (Dz. U. 1927, Nr 83, poz. 736); ustawa skarbowa z dnia 12 lutego 1931 r. o dodatkowych kredytach na rok 1927/28 (Dz.U. 1931, Nr 35 poz. 261); ustawa skarbowa z dnia 12 lutego 1931 r. o dodatkowych kredytach na rok 1928/29 (Dz.U. 1931, Nr 35, poz. 262). 
Ministrowi Skarbu". Wyliczały także szczegółowo kompetencje do realizacji tak ogólnie sformułowanego obowiązku. Można je podzielić na kilka grup.

Po pierwsze, w ustawach skarbowych okresu międzywojennego określono uprawnienie ministra skarbu do „otwierania kredytów”, czyli upoważnienia do uruchomienia dla poszczególnych dysponentów kwot wydatków przyznanych w preliminarzu. Upoważnienie to miało charakter kasowy i raczej techniczny, pozwalający na kontrolę realizacji kwot wydatków na poziomie przewidzianym w budżecie. Nie wiązało się jednak z prawną możliwością zablokowania wydatków przez ministra skarbu, jeśli dotyczyło to kwot uprzednio zaplanowanych w budżecie.

Po drugie, w ramach upoważnienia do udzielania zgody na „otwieranie kredytów" kompetencją o dużo większym znaczeniu gatunkowym było prawo ministra do miesięcznego ustalania wysokości kredytów ${ }^{56}$, co w literaturze określano jako budżetowanie miesięczne ${ }^{57}$ lub budżety miesięczne ${ }^{58}$. Konstrukcja ta opierała się na założeniu, że minister skarbu w ramach uchwalonej w ustawie skarbowej kwoty ogólnej rocznych wydatków na każdy miesiąc odrębnie ustalał granice wydatków dla poszczególnych dysponentów. Zatem ustawa skarbowa wyznaczała górny limit wydatków, w rzeczywistości zaś podstawą dokonywania wydatków przez dysponentów ${ }^{59}$ był ustalony przez ministra skarbu budżet miesięczny. Należy podkreślić, że przepisy nie wskazywały szczegółowych zasad, jakimi minister skarbu miał się kierować w budżetowaniu miesięcznym ${ }^{60}$. Od początku budżet miesięczny był traktowany jako instrument służący uzyskaniu równowagi budżetowej i zapobiegający ujemnym konsekwencjom nierealności budżetu, a także techniczny środek urzeczywistnienia programu oszczędności ${ }^{61}$. Uprawnienie to było oceniane jako „zupełne panowanie Ministra Skarbu nad wykonaniem budżetu”, a z punktu widzenia relacji ministra skarbu z innymi ministrami jako „rodzaj dyktatury finansowej”62. Taką ocenę uzasadniał brak publikacji budżetów miesięcznych, czyli ograniczenie zasady jawności. W efekcie budżetowanie miesięczne było uznawane za skuteczny środek do osiągnięcia równowagi budżetowej, „kładący kres beztrosce budżetowej”,

${ }^{56}$ Po raz pierwszy zostało ono wprowadzone art. 5 ustawy skarbowej na rok 1924 (Dz.U. 1924, Nr 76, poz. 747). Idea ta została zawarta w sprawozdaniu przygotowanym przez E. Hiltona Younga dla Prezesa Rady Ministrów. Zob. E. Hilton Young, O położeniu finansowym Polski, LwówWarszawa 1924, s. 85-86.

57 T. Grodyński, Zasady gospodarstwa budżetowego..., s. 338.

${ }^{58}$ C. Łabanowski, Budżety miesięczne jako środek utrzymania równowagi budżetowej w Polsce, Warszawa 1930.

${ }^{59}$ Wyjątkiem od tej zasady były wydatki Sejmu, Senatu i Najwyższej Izby Kontroli.

${ }^{60}$ T. Grodyński i C. Łabanowski wskazują w swoich opracowaniach na praktykę, jaka rozwinęła się w związku z ustalaniem budżetów miesięcznych. Zob. T. Grodyński, Zasady gospodarstwa budżetowego..., s. 340; C. Łabanowski, Budżety miesięczne..., s. 12-14.

${ }^{61}$ Tak: C. Łabanowski, Budżety miesięczne..., s. 7; A. Dubieński, Stanowisko Ministra Skarbu..., s. 26; T. Grodyński, Zasady gospodarstwa budżetowego..., s. 342.

${ }^{62}$ A. Dubieński, Stanowisko Ministra Skarbu..., s. 29. 
a także środek wychowawczy, „wyrabiający we wszystkich władzach poczucie fiskalne prowadzące do współpracy z Ministrem Skarbu"63.

Po trzecie, ustawy skarbowe z lat 1924-1939 przewidywały uprawnienie ministra skarbu do „otwierania kredytów nieobjętych budżetem”, czyli nieprzewidzianych w ustawie skarbowej. Minister skarbu był upoważniony do złożenia wniosku w tym zakresie, natomiast ustalenie nowych wydatków następowało w drodze ustawy ${ }^{64}$.

Po czwarte, odrębnym uprawnieniem ministra skarbu w toku wykonywania budżetu było wprowadzanie zmian polegających na przeniesieniach wydatków (virement) oraz zwiększaniu niektórych wydatków. Dokonywanie przeniesień wydatków ograniczone było z reguły do wydatków o charakterze administracyjnym. Ponadto przepisy ustaw skarbowych wprowadzały ograniczenia dotyczące przeniesień między podziałkami klasyfikacji budżetowej. Dokonanie przeniesień (vire$m e n t$ ) wymagało także uprzedniego wniosku właściwego dysponenta budżetowego. Charakterystyczne jest również wyłączenie władztwa ministra skarbu w zakresie dokonywania przeniesień w częściach budżetu dotyczących Sejmu, Senatu, NIK na rzecz dysponentów tych części. Innym ograniczeniem była niemożność dokonywania przeniesień na uposażenia (płace). Od 1930 r. minister skarbu miał prawo dokonywać przeniesień wydatków do tzw. rezerwy zaopatrzenia. Jego kompetencja do zwiększania wydatków budżetowych ograniczona była przez ustawy skarbowe tylko do niektórych podmiotów i kategorii wydatków ${ }^{65}$. Warunkiem ich dokonania było dysponowanie środkami na ich pokrycie, a w niektórych przypadkach ustawy skarbowe zakreślały górne granice zwiększania wydatków. Powyższe kompetencje ministra nie wymagały odrębnego zatwierdzenia ani ze strony rządu, ani organów ustawodawczych.

Po piąte, w toku wykonywania budżetu ustawy skarbowe przyznawały ministrowi skarbu prawo do udzielania pożyczek np. bankom państwowym, związkom samorządu terytorialnego czy gospodarczego lub na inne określone expressis verbis cele (np. podniesienie produkcji drobnego rolnictwa).

Po szóste, ustawy skarbowe udzielały ministrowi skarbu ogólnej kompetencji do ustalania zasad wydatkowania środków budżetowych po upływie okresu bu-

${ }^{63}$ C. Łabanowski, Budżety miesięczne..., s. 34.

${ }^{64}$ Ustawa skarbowa z dnia 19 grudnia 1924 r. o dodatkowych kredytach na rok 1924 (Dz. U. 1925, Nr 10, poz. 75); ustawa skarbowa z dnia 22 lipca 1925 r. o dodatkowych kredytach na rok 1925 (Dz. U. 1925, Nr 83, poz. 570); ustawa skarbowa z dnia 12 lutego 1931 r. o dodatkowych kredytach na rok 1927/28 (Dz. U. 1931, Nr 35, poz. 261); ustawa skarbowa z dnia 12 lutego $1931 \mathrm{r}$. o dodatkowych kredytach na rok 1928/29 (Dz.U. 1931, Nr 35, poz. 262).

${ }^{65}$ Przykładem jest uprawnienie do zwiększenia: wydatków przewidzianych w planach finansowo-gospodarczych przedsiębiorstw i monopoli państwowych, z wyjątkiem wydatków osobowych; wydatków przewidzianych w planie finansowo-gospodarczym Funduszu Obrotowego Reformy Rolnej czy wydatków na spłatę zadłużenia w miarę uzyskiwania ich pokrycia. 
dżetowego ${ }^{66}$. Zasadą było bowiem dokonywanie wydatków tylko do końca roku budżetowego. W granicach czasowych zakreślonych przez ustawy skarbowe ${ }^{67}$, a w niektórych przypadkach zakreślonych celach, na jakie mogą być przeznaczone wydatki niewygasające z końcem roku budżetowego, minister skarbu dyrektywnie określał warunki dokonywania tych wydatków. Warto zaznaczyć, że przepisy ustawowe nie określały bliżej trybu działania ministra, pozostawiając mu w tym zakresie swobodę.

Stałą praktyką, wynikającą z przyczyn politycznych lub sytuacji gospodarczej i finansowej państwa w okresie międzywojennym, było uchwalanie prowizorów budżetowych ${ }^{68}$. Polskie ustawy o prowizoriach budżetowych z tego okresu,

${ }^{66} \mathrm{~W}$ przedwojennej literaturze nazywano je „okresem ulgowym”. Zob. T. Grodyński, Zasady gospodarstwa budżetowego..., s. 374.

${ }^{67}$ Ustawy skarbowe wskazywały różne okresy, np. miesięczne, dwumiesięczne lub trzymiesięczne. Niektóre ustawy skarbowe w ogóle nie przewidywały tzw. okresu ulgowego.

${ }^{68}$ W latach 1919-1939 uchwalono aż 22 ustawy o prowizorium budżetowym: ustawa z dnia 15 lutego 1923 r. o prowizorjum budżetowem za czas od 1 stycznia do 31 marca 1923 r. (Dz.U. 1923, Nr 22, poz. 138); ustawa z dnia 24 marca 1923 r. o pierwszem dodatkowem prowizorjum budżetowem za czas od dnia 1 stycznia do dnia 31 marca 1923 r. (Dz.U. 1923, Nr 38, poz. 253); ustawa $\mathrm{z}$ dnia 15 czerwca $1923 \mathrm{r}$. o drugiem dodatkowem prowizorjum za czas od dnia 1 stycznia do dnia 31 marca 1923 r. (Dz.U. 1923, Nr 66, poz. 510); ustawa z dnia 15 czerwca 1923 r. o prowizorjum budżetowem za czas od 1 kwietnia do 30 czerwca 1923 r. (Dz. U. 1923, Nr 66, poz. 511); ustawa z dnia 8 sierpnia 1923 r. o prowizorjum budżetowem za czas od 1 lipca do 30 września $1923 \mathrm{r}$. (Dz.U. 1923, Nr 89, poz. 698); ustawa z dnia 25 października 1923 r. o dodatkowem prowizorjum budżetowem za czas od 1 lipca do 30 września 1923 r. oraz o prowizorjum budżetowem za czas od 1 października do 31 grudnia 1923 r. (Dz.U. 1923, Nr 112, poz. 892); ustawa z dnia 10 stycznia 1924 r. o dodatkowem prowizorjum budżetowem za czas od 1 października do 31 grudnia 1923 r. (Dz.U. 1924, Nr 4, poz. 26); ustawa z dnia 10 stycznia 1924 r. o prowizorjum budżetowem na czas od 1 stycznia do 31 marca 1924 r. (Dz. U. 1924, Nr 4, poz. 27); ustawa z dnia 11 kwietnia 1924 r. o prowizorjum budżetowem na czas od 1 kwietnia do 30 czerwca 1924 r. (Dz. U. 1924, Nr 40, poz. 422); ustawa $\mathrm{z}$ dnia 19 grudnia $1924 \mathrm{r}$. o prowizorjum budżetowem na czas od 1 stycznia do 28 lutego 1925 r. (Dz.U. 1924, Nr 114, poz. 1013); ustawa z dnia 3 marca 1925 r. o prowizorjum budżetowem na czas od 1 marca do 30 kwietnia 1925 r. (Dz.U. 1925, Nr 23, poz. 159); ustawa z dnia 29 kwietnia 1925 r. o prowizorjum budżetowem na czas od 1 maja do 30 czerwca 1925 r. (Dz. U. 1925, Nr 47, poz. 325); ustawa z dnia 22 grudnia 1925 r. o prowizorjum budżetowem na czas od 1 stycznia do 31 marca 1926 r. (Dz.U. 1925, Nr 129, poz. 917); ustawa z dnia 31 marca 1926 r. o uzupełnieniu prowizorjum budżetowego na czas od 1 stycznia do 31 marca $1926 \mathrm{r}$. i o prowizorjum budżetowem na czas od 1 do 30 kwietnia 1926 r. (Dz. U. 1926, Nr 34, poz. 208); ustawa z dnia 30 kwietnia 1926 r. o uzupełnieniu prowizorjum budżetowego na czas od 1 do 30 kwietnia 1926 r. i o prowizorjum budżetowem na czas od 1 maja do 30 czerwca 1926 r. (Dz.U. 1926, Nr 42, poz. 258); ustawa z dnia 1 lipca 1926 r. o uzupełnieniu prowizorjum budżetowego na czas od 1 maja do 30 czerwca 1926 r. i o prowizorjum budżetowem na czas od 1 lipca do 30 września 1926 r. (Dz.U. 1926, Nr 63, poz. 376); ustawa z dnia 30 września 1926 r. o uzupełnieniu prowizorjum budżetowego na czas od 1 lipca do 30 września 1926 r. i o prowizorjum budżetowem na czas od 1 października do 31 grudnia 1926 r. (Dz.U. 1926, Nr 99, poz. 571); ustawa z dnia 18 grudnia 1926 r. o uzupełnieniu prowizorjum budżetowego na czas od 1 października do 31 grudnia $1926 \mathrm{r}$. i o prowizorjum budżetowem na czas od 1 stycznia do 31 marca 1927 r. (Dz.U. 1926, Nr 125, poz. 725); ustawa z dnia 
w przeciwieństwie do współczesnego ich rozumienia oraz teorii wypracowanych w doktrynie przedwojennej ${ }^{69}$, zawierały z reguły szczególne upoważnienia dla ministra skarbu w okresie obowiązywania prowizorium. Dotyczyły one przede wszystkim prawnie uregulowanych możliwości „otwierania kredytów”70, czyli określania nowych oraz uzupełniania lub zmian limitów wydatków. Wynikały one z konieczności reagowania na zmieniającą się sytuację walutową i gospodarczą. Dlatego w literaturze tego okresu nie ocenia się tych uprawnień ministra skarbu jedynie jako instrumentu oddziaływania na innych ministrów, ale raczej jako formę kontrolowania poziomu wydatków w celu osiągnięcia równowagi budżetowej ${ }^{71}$. Ponadto upoważnienia wynikające z prowizoriów dotyczyły pokrywania w określonym czasie wydatków dochodami wskazanymi w tych przepisach, dokonywania operacji finansowych w celu pokrycia deficytu budżetowego, a także uzależniały przekroczenie wydatków ponad dopuszczalne limity od uzyskania zgody ministra skarbu.

Minister skarbu odegrał istotną rolę w unifikacji i opracowaniu systemu kasowo-rachunkowego ${ }^{72}$, wydając początkowo instrukcje dotyczące zasad rachunkowości i sprawozdawczości ${ }^{73}$. Zgodnie z ustawą o kontroli państwowej z 1921 r. przepisy kasowe i rachunkowe mogły być wydawane także przez ministrów w odniesieniu do podległych im jednostek jedynie w porozumieniu z Najwyższą Izbą Kontroli i ministrem skarbu ${ }^{74}$.

V. Ściśle powiązana z gospodarką budżetową jest także sfera pozabudżetowa. Przykładem tego są kompetencje ministra skarbu, dlatego warto rozważyć jego wpływ na monopole państwowe, przedsiębiorstwa państwowe, gospodarkę funduszową czy związki samorządu terytorialnego.

Minister skarbu w okresie międzywojennym był wyposażony w szerokie kompetencje pozwalające mu oddziaływać na monopole państwowe oraz przedsiębiorstwa państwowe. Monopolami państwowymi określano przedsiębiorstwa państwowe posiadające osobowość prawną, eksploatujące trzy najważniejsze

31 marca 1928 r. o prowizorjum budżetowem na czas od 1 kwietnia do 30 czerwca 1928 r. (Dz.U. 1928, Nr 43, poz. 419); ustawa z dnia 12 lutego 1931 r. o uzupełnieniu prowizorjum budżetowego na czas od 1 stycznia do 31 marca 1927 r. (Dz. U. 1931, Nr 24, poz. 139).

${ }^{69} \mathrm{O}$ istocie i prawnym charakterze prowizoriów: T. Grodyński, Zasady gospodarstwa budżetowego..., s. 296-308.

${ }^{70}$ Kredytem budżetowym określano kwoty wydatków budżetowych, w ramach których dokonywane były wydatki przez dysponentów.

${ }^{71}$ A. Dubieński, Stanowisko Ministra Skarbu..., s. 24.

72 Szerzej: T. Grodyński, Zasady gospodarstwa budżetowego..., s. 33; I. Weinfeld, Skarbowość polska, s. 88-93.

${ }^{73}$ Wykaz tych instrukcji wraz z przepisami zmieniającymi: B. Markowski, Administracja skarbowa..., s. 185.

${ }^{74}$ Art. 12 ustawy z dnia 3 czerwca 1921 r. o Kontroli Państwowej (Dz. U. 1921, Nr 51, poz. 314). 
monopole: spirytus ${ }^{75}$, tyton ${ }^{76}$ i sól ${ }^{77}$. Minister skarbu dysponował instrumentami prawnofinansowego oddziaływania na te monopole. Do najważniejszych z nich należały: a) nadzór nad działalnością przedsiębiorstwa i ustalanie ogólnych wytycznych polityki gospodarczej przedsiębiorstwa, $b$ ) ustalanie organizacji wewnętrznej dyrekcji, czyli organu zarządzającego przedsiębiorstwa, c) decydowanie o tworzeniu i kasowaniu zakładów przedsiębiorstwa, d) ustalanie zasad stosunku służbowego i określanie praw i obowiązków pracowników przedsiębiorstwa, e) ustalanie planu finansowo-gospodarczego przedsiębiorstwa, decydowanie o jego zmianach, zatwierdzanie obrachunków rocznych, f) decydowanie o podziale czystego zysku przedsiębiorstwa, g) decydowanie o tworzeniu przez przedsiębiorstwo funduszów, wysokości tych funduszów i dokonywaniu odpisów na nie, h) ustalanie zasad zaciągania przez przedsiębiorstwo pożyczek krótkoterminowych, i) ustalanie warunków udzielania przez przedsiębiorstwo kredytów towarowych, j) ustalanie norm wysokości zapasów wyrobów gotowych, surowców i materiałów pomocniczych, k) możliwość zastrzeżenia innych spraw do własnej aprobaty ${ }^{78}$.

Jak już wspomniano, w ramach wykonywania budżetu na podstawie ustaw skarbowych minister skarbu miał prawo dokonywać przeniesień wydatków oraz podwyższać wydatki przewidziane w planach finansowo-gospodarczych.

Jeśli chodzi o przedsiębiorstwa państwowe, to nie stanowiły one w omawianym okresie jednolitej konstrukcji pod względem prawnofinansowym ${ }^{79}$. Z uwagi na kompetencje ministra skarbu można wyodrębnić dwie grupy przedsiębiorstw. Pierwszą stanowiły przedsiębiorstwa budżetowo nieskomercjalizowane, których plany finansowo-gospodarcze były włączone do budżetu ${ }^{80}$. Warto odnotować, że podobnie jak w przypadku monopoli (które niekiedy także były zaliczane do tej

75 Rozporządzenie Prezydenta Rzeczypospolitej z dnia 11 lipca 1932 r. o monopolu spirytusowym (Dz. U. 1932, Nr 63, poz. 586).

${ }^{76}$ Ustawa z dnia 18 marca 1932 r. o utworzeniu państwowego przedsiębiorstwa „Polski Monopol Tytoniowy" (Dz.U. 1932, Nr 26, poz. 240).

77 Rozporządzenie Prezydenta Rzeczypospolitej z dnia 21 czerwca 1932 r. o przedsiębiorstwie „Polski Monopol Solny” (Dz. U. 1932, Nr 52, poz. 497).

${ }^{78} \S 4$ rozporządzenia Ministra Skarbu z dnia 10 stycznia 1933 r. o organizacji przedsiębiorstwa państwowego „Polski Monopol Tytoniowy” (Dz.U. 1933, Nr 4, poz. 25); § 4 rozporządzenia Ministra Skarbu z dnia 10 stycznia 1933 r. o organizacji przedsiębiorstwa państwowego „Polski Monopol Solny” (Dz.U. 1933, Nr 4, poz. 26); § 4 rozporządzenia Ministra Skarbu z dnia 10 stycznia 1933 r. o organizacji przedsiębiorstwa państwowego „Państwowy Monopol Spirytusowy” (Dz.U. 1933, $\mathrm{Nr}$ 4, poz. 27).

${ }^{79}$ C. Kosikowski, Pozycja prawna Ministra Skarbu..., s. 68; idem, Opodatkowanie przedsiębiorstw państwowych w Polsce międzywojennej, „Zeszyty Naukowe UŁ” 1971, z. 83, s. 165 i n.

${ }^{80}$ Przykładami tych przedsiębiorstw były: Polska Ajencja Telegraficzna, drukarnie państwowe, zdrojowiska państwowe, Mennica Państwowa, Polska Poczta Telegraf i Telefon. Pewne odmienności wykazywało jedynie przedsiębiorstwo Polskie Lasy Państwowe. Zob. T. Grodyński, Zasady gospodarstwa budżetowego..., s. 138 i n. 
grupy), minister skarbu posiadał szerokie kompetencje oddziaływania na ich gospodarkę finansową. Strona wydatkowa i dochodowa tej kategorii przedsiębiorstw była ujęta w preliminarzu redagowanym przez ministra skarbu. Na podstawie ustaw skarbowych był on upoważniony do dokonywania przeniesień wydatków i zwiększania wydatków w toku wykonywania budżetu. Drugą grupę stanowiły przedsiębiorstwa budżetowo skomercjalizowane ${ }^{81}$, których plany finansowo-gospodarcze nie były włączone do budżetu ${ }^{82}$. W budżecie ujęte były jedynie kwoty wpłat $\mathrm{z}$ tytułu zysku bilansowego. Funkcja ministra skarbu sprowadzała się w tym przypadku do zadań kontrolnych. Była realizowana poprzez jego udział w zatwierdzeniu bilansu, rachunku strat i zysków oraz podziału czystego zysku przedsiębiorstwa ${ }^{83}$. Minister skarbu powoływał jednego członka w skład dziewięcioosobowej Rady Administracyjnej (organ zarządzający), a także członków Komisji Rewizyjnej. Ten ostatni organ zobowiązany był do przedkładania mu sprawozdań pokontrolnych.

Inną płaszczyzną oddziaływania ministra skarbu była gospodarka funduszowa. W okresie międzywojennym funkcjonowało kilkanaście funduszy państwowych. Nie miały one jednolitej konstrukcji ani wspólnych zasad gospodarki finansowej, powoływane były do realizacji różnych zadań oraz finansowane z różnych źródeł ${ }^{84}$. Należy jednak wskazać, że część planów finansowo-gospodarczych funduszy była ujmowana w preliminarzu budżetowym, zaś ustawy skarbowe upoważniały ministra skarbu do dokonywania przeniesień wydatków i zwiększania wydatków na takich samych zasadach jak w przypadku przedsiębiorstw nieskomercjalizowanych, o których była mowa wyżej ${ }^{85}$. Akty normatywne określające zasady funkcjonowania niektórych funduszy państwowych w sposób wyraźny przyznawały szerokie kompetencje w zakresie gospodarki finansowej ministrowi skarbu ${ }^{86}$. Przedwojenna

${ }^{81}$ Rozporządzenie Prezydenta Rzeczypospolitej z dnia 17 marca 1927 r. o wydzielaniu z administracji państwowej przedsiębiorstw państwowych, przemysłowych, handlowych i górniczych oraz o ich komercjalizacji (Dz.U. 1927, Nr 25, poz. 195).

82 Przykładami tych przedsiębiorstw były: Państwowe Wytwórnie Uzbrojenia, Państwowa Wytwórnia Prochu i Materiałów Kruszących, Państwowe Zakłady Inżynierii, Państwowe Zakłady Lotnicze, Żegluga Polska, Polskie Koleje Państwowe.

${ }^{83}$ Sprawozdanie zawierające bilans oraz rachunek strat i zysków za ostatni rok sprawozdawczy było dołączane do preliminarza budżetowego.

${ }^{84}$ Biorąc po uwagę kryterium źródła finansowania, T. Grodyński podzielił fundusze na trzy grupy: utworzone z wpływów pożyczkowych, dotowane z podatków celowych oraz utworzone $\mathrm{z}$ dotacji budżetowych lub pozabudżetowych. Zob. T. Grodyński, Zasady gospodarstwa budżetowego..., s. 181-183.

${ }^{85}$ Art. 7 ustawy skarbowej z dnia 28 lutego 1933 r. na okres od 1 kwietnia 1933 do 31 marca 1934 r. (Dz.U. 1933, Nr 23, poz. 186).

${ }^{86}$ Przykładem może być Państwowy Fundusz Budowlany, dla którego ustalenie wysokości dotacji, sposobu podziału środków i innych kompetencji należało do ministra skarbu - zob. art. 15-20 rozporządzenia Prezydenta Rzeczypospolitej z dnia 22 kwietnia 1927 r. o rozbudowie miast (Dz. U. 1927, Nr 42, poz. 372). Innym przykładem może być Państwowy Fundusz Drogowy, w przypadku którego tylko minister skarbu mógł zatwierdzać pożyczki i udzielać mu gwarancji, a także wpływać 
gospodarka funduszowa nie była uporządkowana, zróżnicowane były kompetencje poszczególnych ministrów, w tym ministra skarbu, wobec funduszy państwowych, dlatego jej analiza nie jest tu możliwa ${ }^{87}$.

Jeśli chodzi kompetencje w zakresie skarbowości samorządu terytorialnego, to minister skarbu, działający w porozumieniu z ministrem spraw wewnętrznych, był wskazany jako ,władza nadzorcza” w sprawach dotyczących finansów komunalnych ${ }^{88}$. Przedmiotowo władze nadzorcze miały kompetencje do zatwierdzania uchwał podatkowych, porozumień dotyczących określania udziałów we wpływach z niektórych podatków (podatek od kopalń), zatwierdzania uchwał w sprawach zaciągania pożyczek i udzielania poręczeń. Także w zakresie spraw budżetowych minister skarbu wraz z ministrem spraw wewnętrznych wskazani zostali jako władza nadzorcza. W ramach uprawnień nadzorczych minister skarbu zatwierdzał preliminarze budżetowe oraz miał prawo żądać wyjaśnień lub dokonywać zmian w tych preliminarzach ${ }^{89}$. Ponadto związki komunalne były zobowiązane przedkładać ministrowi spraw wewnętrznych i ministrowi skarbu budżety lub zestawienia budżetów oraz periodyczne tymczasowe zamknięcia rachunkowe z okresu bieżącego lub ich zestawienia. Odrębnym uprawnieniem nadzorczym ministra skarbu w porozumieniu z ministrem spraw wewnętrznych była możliwość badania gospodarki związków komunalnych przez własnych delegatów, którzy mieli prawo zasięgać informacji o działalności związków komunalnych, żądać przedłożenia ich uchwał i aktów w celu zaznajomienia się z ich treścią, zwiedzać zakłady, urządzenia i przedsiębiorstwa komunalne, prowadzić dochodzenia na miejscu, dokonywać rewizji ksiąg i kas. Brak samodzielności działania ministra skarbu przejawiał się w tym, że o ile minister ten na podstawie sprawozdań swoich delegatów lub przedkładanych mu budżetów i zamknięć rachunkowych stwierdził nieprawidłowości natury finansowej lub brak oszczędności w gospodarce związku

na jego budżet - zob. art. 3-4 ustawy z dnia 3 lutego 1931 r. o Państwowym Funduszu Drogowym (Dz. U. 1933, Nr 45, poz. 352).

87 Szerzej: T. Grodyński, Zasady gospodarstwa budżetowego..., s. 179-189; I. Weinfeld, Skarbowość polska, s. 65-70; J. Stankiewicz, Debudżetyzacja finansów państwa, Białystok 2007, passim oraz podana tam literatura.

${ }_{88}$ Art. 20, 37, 38 ustawy z dnia 11 sierpnia 1923 r. o tymczasowem uregulowaniu finansów komunalnych (Dz.U. 1923, Nr 94, poz. 747 z późn. zm.). Kompetencje te zostały przekazane do właściwości wojewodów i dyrektorów izb skarbowych na podstawie rozporządzenia Ministra Spraw Wewnętrznych z dn. 15 kwietnia 1924 r. wydane w porozumieniu z Ministrem Skarbu, w przedmiocie przekazania wojewodom (delegatowi Rządu w Wilnie) i dyrektorom izb skarbowych niektórych uprawnień Ministra Spraw Wewnętrznych i Ministra Skarbu, wynikających z ustawy z dn. 11 sierpnia 1923 r. o tymczasowem uregulowaniu finansów komunalnych (Dz. U. 1924, Nr 36, poz. 390).

${ }^{89} \S 8$ rozporządzenia Prezydenta Rzeczypospolitej z dnia 17 czerwca 1924 r. o obowiązku i sposobie pokrywania wydatków przez związki komunalne (Dz.U. 1924, Nr 51, poz. 522). 
komunalnego, to miał obowiązek zawiadomienia o nich ministra spraw wewnętrznych celem wydania stosownych zarządzeń ${ }^{90}$.

VI. Odrębnym polem analiz pozycji ministra skarbu w okresie II RP jest jego rola $\mathrm{w}$ procesach związanych $\mathrm{z}$ długiem publicznym. W literaturze przedmiotu okresu międzywojennego dość rzadko odnoszono się w sensie ścisłym do kategorii deficytu i długu publicznego, określając ten pierwszy raczej jako niedobór ${ }^{91}$, a drugi jako dług państwowy ${ }^{92}$ lub dług Rzeczypospolitej ${ }^{93}$. Inne było także podejście do zasady równowagi budżetowej, której zachowanie uważane było za warunek sine qua non prawidłowego prowadzenia gospodarki budżetowej ${ }^{94}$. Status prawny ministra skarbu, jak wyżej wspomniano, był analizowany przez pryzmat możliwości wykorzystania przez niego uprawnień w celu zachowania równowagi budżetowej. Takie praktyczne i naukowe podejście sprawiło, że w przypadku okresu przedwojennego nie można mówić o uprawnieniach ministra skarbu w zakresie zarządzania długiem. Niemniej na podstawie obowiązującego ustawodawstwa można wnioskować o przyznaniu mu takich kompetencji. Zarówno Konstytucja marcowa ${ }^{95}$, jak i kwietniowa ${ }^{96}$ przewidywały, że: zaciąganie pożyczek, udzielanie gwarancji przez Skarb Państwa wymagało formy ustawy ${ }^{97}$. Również przed uchwaleniem Konstytucji marcowej zasada ta była respektowana ${ }^{98}$. Warto dodać, że w okresie międzywojennym odrębne ustawy przewidywały zasady wykonywania parlamentarnej kontroli

90 § 12 rozporządzenia Prezydenta Rzeczypospolitej z dnia 17 czerwca 1924 r. o obowiązku i sposobie pokrywania wydatków przez związki komunalne (Dz.U. 1924, Nr 51, poz. 522). Por. S. Głąbiński, Polskie prawo skarbowe, Lwów 1928, s. 42 i n.

${ }_{91}$ I. Czuma, Równowaga budżetu..., s. 43.

92 T. Grodyński, Zasady gospodarstwa budżetowego..., s. 49.

93 E. Taylor, Prawo skarbowe Rzeczypospolitej Polskiej, Poznań 1920, s. 116.

${ }^{94}$ E. Schmidt pisał, że „państwo o stałym deficycie budżetowym nie może istnieć”. Zob. E. Schmidt, Równowaga budżetowa w Polsce, Poznań 1922, s. 6. Szerzej na temat równowagi budżetowej: I. Czuma, Równowaga budżetu...; S. Nowak, Równowaga budżetowa [w:] Na froncie gospodarczym. $W$ dziesiąta rocznicę odzyskania niepodległości 1918-1928, Warszawa 1928, s. 192 i n.

${ }_{95}$ Art. 6 Konstytucji marcowej.

${ }^{96}$ Art. 51 Konstytucji kwietniowej.

97 Przed wejściem w życie Konstytucji marcowej na podstawie dekretu Rady Regencyjnej Królestwa Polskiego z dnia 30 października 1918 r. w sprawie wypuszczenia pożyczki państwowej (Dz.U. 1918, Nr 14, poz. 32) minister skarbu został upoważniony do wydania zarządzeń w celu zaciągnięcia pożyczki państwowej.

${ }^{98}$ Uchwała Sejmu z dnia 20 lutego 1919 r. o powierzeniu Józefowi Piłsudskiemu dalszego sprawowania urzędu Naczelnika Państwa (Dz.U. 1919, Nr 44, poz. 312) wprowadziła zasadę, że emisja biletów Polskiej Krajowej Kasy Pożyczkowej lub innych biletów obciążających Skarb Państwa, zaciąganie pożyczek państwowych i przyjmowanie przez państwo gwarancji finansowych nie może nastąpić bez uprzedniego zezwolenia Sejmu. 
nad długami państwa przez specjalną Komisję Kontroli Długów Państwa ${ }^{99}$. Z aktów tych wynikały obowiązki ministra skarbu dotyczące przedkładania informacji Komisji Kontroli Długów Państwa o zmianach w stanie długów i gwarancji państwa oraz wszelkich dokumentów związanych z tą problematyką ${ }^{100}$.

W ówczesnej literaturze przedmiotu ${ }^{101}$ wskazywano cztery kategorie zadłużenia publicznego: a) kredyty w Polskiej Krajowej Kasie Pożyczkowej w latach 1919-1924 ${ }^{102}$, Banku Polskim lub w innych bankach ${ }^{103}$, b) pożyczki wewnętrzne, c) pożyczki zagraniczne, d) gwarancje państwowe. W odniesieniu do każdej z tych kategorii ministrowi skarbu były ustawowo udzielane upoważnienia do podejmowania szczegółowych działań.

Na podstawie odrębnych ustaw ${ }^{104} \mathrm{w}$ okresie funkcjonowania Polskiej Krajowej Kasy Pożyczkowej, a po jej likwidacji w Banku Polskim lub Banku Gospodarstwa Krajowego minister skarbu upoważniany był przez Sejm do zaciągania pożyczek lub kredytów w kwotach i terminach w nich określonych w celu pokrycia „,niedoboru" lub na bieżące potrzeby budżetowe ${ }^{105}$.

99 Ustawa z dnia 25 września 1922 r. o kontroli nad długami państwa (Dz. U. 1922, Nr 89, poz. 805), a następnie ustawa z dnia 2 stycznia 1936 r. o wykonywania kontroli parlamentarnej nad długami państwa (Dz.U. 1936, Nr 2, poz. 3).

100 Szerzej: Z. Ofiarski, Państwowy dtug publiczny [w:] E. Ruśkowski (red.), System prawa finansowego. Prawo finansowe sektora finansów publicznych, t. II, Warszawa 2010, s. 139 i n.

101 Tak: E. Taylor, Prawo skarbowe Rzeczypospolitej Polskiej..., s. 116; por. J. Zdziechowski, Finanse Polski w świetle budżetów 1924-1925 roku, Warszawa 1925, s. 4 i n.; E. Strasburger, Ocena prawa skarbowego $w$ Polsce [w:] Reforma skarbowa $w$ Polsce. Referaty z nadzwyczajnego zebrania Towarzystwa Naukowego Ekonomistów i Statystyków Polskich, Warszawa 1922, s. 21; J. Dmochowski, Waluta a pożyczka [w:] Reforma skarbowa w Polsce.., s. 41 i n.

${ }^{102}$ Ustawa z dnia 7 grudnia 1918 r. o Polskiej Krajowej Kasy Pożyczkowej (Dz.U. 1918, Nr 19, poz. 56). W 1924 r. Polska Krajowa Kasa Pożyczkowa została zlikwidowana - zob. ustawa z dnia 11 stycznia 1924 r. o naprawie Skarbu Państwa i reformie walutowej (Dz.U. 1924, Nr 4 poz. 28); rozporządzenie Prezydenta Rzeczypospolitej z dnia 1 lutego 1924 r. o zamknięciu kredytu dla Skarbu Państwa w Polskiej Krajowej Kasie Pożyczkowej i o nadzorze nad jej działalnością emisyjną i kredytową (Dz. U. 1924, Nr 12, poz. 24).

${ }^{103}$ Ustawa z dnia 4 października 1921 r. w przedmiocie upoważnienia Ministra Skarbu do zaciągnięcia w Polskim Banku Krajowym pożyczki w kwocie 120.001 .000 mk (Dz. U. 1921, Nr 83, poz. 582); rozporządzenie Prezydenta Rzeczypospolitej z dnia 20 grudnia 1924 r. w sprawie zaciągnięcia przez Skarb Państwa w Banku Gospodarstwa Krajowego pożyczki w kwocie 23.000 .000 zł w 8\% obligacjach komunalnych (Dz. U. 1924, Nr 118, poz. 1074); ustawa z dnia 23 czerwca 1923 r. w przedmiocie upoważnienia Ministra Skarbu do zaciągnięcia w Polskim Banku Krajowym pożyczki w kwocie 12 miljardów marek (Dz.U. 1923, Nr 66, poz. 513).

104 Początkowo pożyczki w Polskiej Krajowej Kasie Pożyczkowej zaciągane były bez ustawowego upoważnienia, np. na podstawie prowizoriów budżetowych. Szerzej: E. Taylor, Prawo skarbowe Rzeczypospolitej Polskiej..., s. 116-123.

105 Ustawa z dnia 30 maja 1919 r. w przedmiocie dalszego kredytu dla Skarbu Państwa w wysokości pięciuset miljonów marek w Polskiej Kasie Pożyczkowej (Dz. U. 1919, Nr 44, poz. 312); ustawa z dnia 16 lipca 1920 r. w przedmiocie otworzenia dla skarbu kredytu w Polskiej Krajowej Kasie Pożyczkowej (Dz.U. 1920, Nr 63, poz. 413); ustawa z dnia 26 listopada 1920 r. o kredycie 
Odrębne źródło długu stanowiły tzw. pożyczki wewnętrzne, zaciągane w drodze emisji papierów dłużnych (obligacji, bonów skarbowych, listów, rent, biletów itd. $)^{106}$. Na podstawie ustawowo określonych warunków minister skarbu był delegowany do wydawania aktów wykonawczych przewidujących szczegółowe zasady emisji i wykupu papierów wartościowych, a także bezpośrednio do dokonywania czynności związanych z tą emisją ${ }^{107}$. Był on także podmiotem upoważnionym ustawowo do zaciągania pożyczek zagranicznych oraz do emisji papierów wartościowych. Posiadał też pełnomocnictwa do zawierania umów ich sprzedaży z zagranicznymi instytucjami ${ }^{108}$. Brak z reguły dokładnych wytycznych sprawiał, że ustalanie warunków pożyczek pozostawiano ministrowi, co było w ówczesnym piśmiennictwie oceniane jako znaczna swoboda ${ }^{109}$. W odniesieniu do zobowiązań

Skarbu Państwa w Polskiej Krajowej Kasie Pożyczkowej (Dz.U. 1920, Nr 112, poz. 738); ustawa z dnia 8 lipca 1921 r. o kredycie Skarbu Państwa w Polskiej Krajowej Kasie Pożyczkowej (Dz.U. 1921, Nr 64, poz. 402); ustawa z dnia 24 marca 1923 r. o kredycie Skarbu Państwa w Polskiej Krajowej Kasie Pożyczkowej (Dz.U. 1923, Nr 38, poz. 251).

${ }^{106}$ I. Weinfeld, Skarbowość polska, s. 117.

107 Ustawa z dnia 27 lutego 1920 r. w przedmiocie wypuszczenia 5\% krótkoterminowej wewnętrznej pożyczki państwowej z r. 1920 (Dz.U. 1920, Nr 21, poz. 115); ustawa z dnia 27 lutego 1920 r. w przedmiocie wypuszczenia pięcioprocentowej długoterminowej wewnętrznej pożyczki państwowej z r. 1920 (Dz.U. 1920, Nr 25, poz. 52); ustawa z dnia 30 kwietnia 1920 r. o wypuszczeniu serji I biletów skarbowych (Dz.U. 1920, Nr 38, poz. 219); ustawa z dnia 16 lipca 1920 r. w przedmiocie wewnętrznej przymusowej pożyczki państwowej (Dz.U. 1920, Nr 67, poz. 455); ustawa z dnia 28 października 1920 r. w przedmiocie przeprowadzenia wewnętrznej przymusowej pożyczki państwowej (Dz.U. 1920, Nr 105, poz. 692); ustawa z dnia 26 września 1922 r. w przedmiocie wypuszczenia 8\% państwowej pożyczki złotej z 1922 r. (Dz.U. 1922, Nr 83, poz. 741); ustawa z dnia 22 marca 1923 r. w przedmiocie wypuszczenia 6\% złotych bonów skarbowych (Dz.U. 1923, Nr 33, poz. 215); ustawa z dnia 15 lipca 1925 r. o wypuszczeniu biletów skarbowych (Dz.U. 1925, Nr 73, poz. 507); ustawa z dnia 23 marca 1929 r. o upoważnieniu Ministra Skarbu do wypuszczenia wewnętrznej pożyczki państwowej do wysokości 100.000 .000 zł w złocie (Dz. U. 1929, Nr 23, poz. 232); rozporządzenie Prezydenta Rzeczypospolitej z dnia 27 października 1933 r. o podwyższeniu emisji pożyczki wewnętrznej (Dz. U. 1933, Nr 84, poz. 611); ustawa z dnia 26 marca 1935 r. o upoważnieniu Ministra Skarbu do wypuszczenia wewnętrznej pożyczki inwestycyjnej (Dz.U. 1935, Nr 21, poz. 122); dekret Prezydenta Rzeczypospolitej z dnia 14 stycznia 1936 r. o konwersji państwowych pożyczek wewnętrznych (Dz. U. 1936, Nr 3, poz. 10).

${ }^{108}$ Ustawa z dnia 28 marca 1919 r. w sprawie zaciągnięcia pożyczki w wysokości 5 miljardów franków (Dz.U. 1919, Nr 29, poz. 252); rozporządzenie Prezydenta Rzeczypospolitej z dnia 11 lipca 1927 r. o zaciągnięciu krótkoterminowej pożyczki zagranicznej (Dz. U. 1927 r., Nr 62, poz. 545); rozporządzenie Prezydenta Rzeczypospolitej z dnia 30 grudnia 1924 r. o zaciągnięciu pożyczki zagranicznej (Dz.U. 1924, Nr 118, poz. 1066); ustawa z dnia 3 marca 1925 r. o wypuszczeniu pożyczki zagranicznej w dolarach Stanów Zjednoczonych Ameryki (Dz.U. 1925 r., Nr 22, poz. 154); rozporządzenie Prezydenta Rzeczypospolitej z dnia 13 października 1927 r. o planie stabilizacyjnym i zaciągnięciu pożyczki zagranicznej (Dz. U. 1927, Nr 88, poz. 798); ustawa z dnia 12 stycznia 1937 r. o upoważnieniu Ministra Skarbu do zaciągnięcia pożyczek zagranicznych i kredytu zagranicznego we frankach francuskich na cele obrony państwa (Dz. U. 1927, Nr 3, poz. 22).

109 Szczególnie w pierwszych latach po odzyskaniu niepodległości. Zob. E. Taylor, Prawo skarbowe Rzeczypospolitej Polskiej..., s. 121. 
Skarbu Państwa z tytułu gwarancji i poręczeń także w tym wypadku minister skarbu był bezpośrednio upoważniony ustawowo do udzielania gwarancji lub poręczeń Skarbu Państwa. Przepisy ustawowe określały maksymalną wysokość i rodzaj zobowiązań, które mogły być przedmiotem gwarancji bądź poręczeń, natomiast ministrowi skarbu powierzały określanie szczegółowych warunków poręczeń i gwarancji oraz zakresu odpowiedzialności Skarbu Państwa ${ }^{110}$.

VII. Przy ministrze skarbu działała Rada Finansowa jako organ doradczy ${ }^{111}$. Jej zadaniem było wydawanie opinii w ważniejszych kwestiach finansowych oraz w sprawach ustawodawstwa skarbowego. Natomiast zdecydowanie ważniejszą rolę pełnił Komitet Ekonomiczny Ministrów, któremu w latach 1923-1926 przewodniczył minister skarbu ${ }^{112}$, a jego sekretariat wchodził w skład Ministerstwa Skarbu. W 1926 r. zmieniono regulamin Komitetu Ekonomicznego Rady Ministrów ${ }^{113}$. Funkcję przewodniczącego sprawował Prezes Rady Ministrów, natomiast minister skarbu pozostał jego członkiem stałym ${ }^{114}$. Do kompetencji Komitetu Ekonomicznego Ministrów należało rozpatrywanie spraw dotyczących programów i ogólnych zasad polityki ekonomicznej rządu, wniosków ustawodawczych z dziedziny gospodarczej, wszelkich spraw o znaczeniu ekonomicznym, rozpatrywanie i uzgadnianie wszelkich spraw natury gospodarczej należących do zakresu działania kilku resortowych ministrów, rozpatrywania i rozstrzygania spraw przekazanych Komitetowi do ostatecznej decyzji, spraw należących do zakresu działania poszczególnych ministrów, np. kredytów, gwarancji, pożyczek rządowych, umów rządowych do-

${ }^{110}$ Ustawa z dnia 19 listopada 1920 r. o upoważnieniu Ministra Skarbu do udzielania gwarancji finansowej do sumy 400.000.000 marek polskich (Dz.U. 1920, Nr 112, poz. 634); ustawa z dnia 4 lipca 1923 r. w przedmiocie udzielenia gwarancji Skarbu Państwa do sumy 10 miljardów marek dla pożyczki na budowę domów dla robotników reemigrujących z Niemiec (Dz. U. 1923, Nr 75, poz. 584); ustawa z dnia 1 lipca 1925 r. o udzielaniu poręki państwowej (Dz.U. 1925, Nr 68, poz. 481); ustawa z dnia 10 marca 1932 r. o udzielaniu poręki państwowej (Dz.U. 1932, Nr 33, poz. 341).

111 Powołana została ustawą z dnia 17 grudnia 1921 r. o środkach naprawy państwowej gospodarki skarbowej (Dz.U. 1921, Nr 103, poz. 741), ale dopiero po wydaniu rozporządzenia Prezydenta Rzeczypospolitej z 10 grudnia 1926 r. o utworzeniu Rady Finansowej przy Ministrze Skarbu (Dz.U. 1926, Nr 121, poz. 695) rozpoczęła swoją działalność. Regulamin został jej nadany przez ministra skarbu - zob. rozporządzenie Ministra Skarbu z 23 maja 1927 r. (Dz. Urz. MS z 1927, Nr 16, poz. 182). Warto dodać, że oprócz Rady Finansowej przy ministrze skarbu działały także inne ciała doradcze: Rada Spółdzielcza, Komitet Bankowy, Rada Ubezpieczeniowa i Rada Mennicza. Zob. C. Kosikowski, Pozycja Ministra Skarbu..., s. 38.

112 Regulamin Komitetu Ekonomicznego Ministrów zatwierdzony uchwałą Rady Ministrów z 21 lutego 1923 r. (M.P. 1923, Nr 48, poz. 46).

113 Regulamin Komitetu Ekonomicznego zatwierdzony uchwałą Rady Ministrów z 29 października 1926 r. (M.P. 1926, Nr 260, Nr 734).

114 Jak stwierdza B. Markowski, z uwagi na charakter kompetencji rola ministra skarbu w pracach komitetu była „wybitna”. Zob. B. Markowski, Administracja skarbowa..., s. 117. 
tyczących eksportu lub importu. Minister skarbu jako przewodniczący Komitetu Ekonomicznego Ministrów wprowadzał wnoszone przez ministrów sprawy pod obrady, a w głosowaniu większością głosów przysługiwało mu prawo do głosu rozstrzygającego.

Minister skarbu w okresie międzywojennym był wyposażony także w inne, stosunkowo szerokie kompetencje. Do najważniejszych należy zaliczyć uprawnienia $\mathrm{w}$ zakresie spraw podatkowych ${ }^{115}$, w tym tworzenia i określania właściwości „władz skarbowych” (np. mógł zmieniać lub ograniczać tok instancji). Stanowił organ „ostatniej instancji” w sprawach, w których organy skarbowe były właści$w^{116}$. Miał szerokie uprawnienia na płaszczyźnie prawotwórczej-przygotowywał projekty ustaw oraz aprobował projekty innych organów, jeśli pociągały za sobą wydatki, a także był delegowany do wydawania aktów wykonawczych ${ }^{117}$. Prowadził politykę finansową, celną, monetarną i kredytową państwa. Był najwyższym organem nadzorczym wobec instytucji kredytowych, ubezpieczeniowych, spółdzielni, banków, w tym Banku Polskiego. Kompetencje ministra skarbu wykraczały także poza tradycyjną materię skarbową. Przykładem mogą być jego specjalne uprawnienia $\mathrm{w}$ zakresie ustalania i likwidacji strat wojennych czy odbudowy. Ponadto w ramach Ministerstwa Skarbu funkcjonowały: Urząd Kontroli Ubezpieczeń, Komenda Straży Granicznej, a jako odrębne komórki: Komitety Likwidacyjne, Biuro Znaków Wartościowych, Komisariat Bankowy, Urząd Długów Państwa, Rada Towaroznawcza. Ministrowi skarbu podlegały m.in. Mennica Państwowa i Prokuratoria Generalna ${ }^{118}$. Należy dodać, że pod względem organizacyjnym minister skarbu wykonywał swoje funkcje za pośrednictwem Ministerstwa Skarbu ${ }^{119}$. Struktura Ministerstwa Skarbu określona była w aktach wykonawczych Rady Ministrów w postaci statutów organizacyjnych ${ }^{120}$.

115 Szerzej: B. Kucia-Guściora, Minister finansów [w:] P. Smoleń (red.), System organów podatkowych w Polsce, Warszawa 2009, s. 63 i n.; C. Kosikowski, Pozycja prawna Ministra Skarbu..., s. 55-69.

116 I. Weinfeld, Skarbowość polska, s. 31.

117 C. Kosikowski, dokonując zestawienia i podsumowania działalności na płaszczyźnie prawotwórczej w dziedzinie finansów, wskazał, że rozporządzenia wykonawcze ministra skarbu w latach 1921-1939 stanowiły 75,45\% tego rodzaju aktów. Zob. C. Kosikowski, Pozycja prawna Ministra Skarbu..., s. 56.

118 Prokuratoria Generalna podlegała ministrowi skarbu od 1924 r. - zob. rozporządzenie Prezydenta Rzeczypospolitej z dnia 9 grudnia 1924 r. o zmianie ustroju Prokuratorji Generalnej Rzeczypospolitej Polskiej (Dz.U. 1924, Nr 107, poz. 967). Szerzej: C. Kosikowski, Pozycja prawna Ministra Skarbu..., s. 58 i n.; I. Weinfeld, Skarbowość polska, s. 29 i n.

119 Rozporządzenie Rady Ministrów z dnia 28 października 1920 r. w sprawie organizacji i zasad urzędowania Ministerstw (M.P. 1920, Nr 251); rozporządzenie Rady Ministrów z dnia 25 sierpnia 1926 r. w sprawie zasad organizacji i urzędowania Ministerstw (M.P. 1926, Nr 203, poz. 578).

${ }^{120}$ Według statutu organizacyjnego Ministerstwo Skarbu składało się z ośmiu departamentów. Zob. rozporządzenie Rady Ministrów z dnia 28 sierpnia 1927 r. w sprawie statutu organizacyjnego Ministerstwa Skarbu (M.P. 1927, Nr 208, poz. 535). Szerzej: S. Głąbiński, Polskie prawo skar- 
VIII. Podsumowując przedstawione rozważania, można stwierdzić, że w okresie międzywojennym, co było uzasadnione sytuacją odradzającego się państwa, minister skarbu został wyposażony w liczne, choć ramowo określone kompetencje, które pozwalały mu szeroko oddziaływać na gospodarkę finansową państwa. Znamienny był brak kompleksowej regulacji prawnej w tej materii, co przekładało się na znaczną kazuistykę i rozproszenie podstaw prawnych działalności ministra. W okresie II RP zauważalna była tendencja do wzmacniania pozycji ministra skarbu. Przejawy swoistej centralizacji jego władzy w sprawach budżetowych można zauważyć na wielu płaszczyznach. Po pierwsze, był on organem, któremu w okresie odbudowy państwa powierzono instrumenty naprawy państwowej gospodarki skarbowej. Po drugie, miał niezachwianą pozycję w procedurze budżetowej, co przejawiało się na wszystkich jej etapach. Po trzecie, na etapie wykonywania budżetu jego kompetencje, jako że kształtowane były w corocznych ustawach skarbowych i ustawach o prowizoriach skarbowych, dostosowywane były do aktualnych potrzeb, nie tylko gospodarczych, ale i politycznych. Ich analiza uprawnia do stwierdzenia, że na etapie wykonania budżetu rola ministra skarbu była dominująca względem innych dysponentów środków budżetowych. Po czwarte, odgrywał on istotną rolę w kształtowaniu i unifikacji procesów sprawozdawczych i kasowych, choć nie można ich w pełni postrzegać w dzisiejszym ujęciu realizacji zasady jawności i przejrzystości. Po szóste, był wyposażony w prawne instrumenty oddziaływania na funkcjonowanie wielu podmiotów niepowiązanych bezpośrednio $\mathrm{z}$ budżetem, m.in.: monopoli państwowych, przedsiębiorstw państwowych, funduszy państwowych czy ówczesnego samorządu terytorialnego.

Znamienne jest też to, że pozycja prawna przedwojennego ministra skarbu w porównaniu z powojennym ministrem finansów była znacznie silniejsza. Wpływ na zmianę statusu powojennego ministra finansów miały przemiany systemowe, związane z nowymi warunkami polityczno-gospodarczymi, w szczególności z realizacją koncepcji gospodarki planowej. Te uwarunkowania przyniosły osłabienie pozycji ministra finansów, gdyż ograniczały jego samodzielność i autonomię działania na rzecz Rady Ministrów oraz Państwowej Komisji Planowania Gospodarczego.

THE STATUS OF THE MINISTER OF THE TREASURY

IN RELATION TO BUDGETARY ISSUES IN THE SECOND POLISH REPUBLIC

\section{Abstract}

The article presents issues related to the role and legal position of the Minister of the Treasury in the period of the Second Polish Republic. While analyzing the Minister's competences concerning budgetary economy, specific aspects of centralization of power

bowe..., s. 11; B. Markowski, Administracja skarbowa..., s. 121; C. Kosikowski, Pozycja prawna Ministra Skarbu..., s. 57. 
are pointed out in the paper as well as the domination of the Minister of the Treasury in the budgetary procedure and his influence on the so-called "extra-budgetary economy" of the financial system. The Minister of the Treasury was entrusted with a very wide range of legal instruments which pertained to various activities connected with planning and the implementation of treasury acts. Another important element which attests to the privileged position of the Minister of the Treasury was his authority in matters related to the incurrence and management of the public debt. Moreover, the Minister's mainly supervisory functions concerning state monopolies, state enterprises, funds, and local government were of considerable importance.

Keyw ords: Minister of the Treasury, state budget, budgetary procedure, treasury act, public debt 